\title{
SCNS. 10 Neurobehavioral effects of chronic administration of Cimicifuga racemosa (I.) nutt. extract in mice
}

\author{
FROTA, A.F.A, SOUZA, R.B. ${ }^{B}$, BEZERRA, M.M.', CUNHA, R.M.S. ${ }^{C}$, AGUIAR, L.M.V.A. \\ aMedicine Faculty of the Federal University of Ceará, Sobral - Ce - Brazil; \\ ${ }^{\mathrm{b} B i o c h e m i s t r y}$ and Molecular Biology Department of the Federal University of Ceará, \\ Fortaleza - Ce - Brazil \\ 'Biological Sciences Center of the State University of Acaraú Valley, Sobral - Ce - Brazil.
}

Introduction: Currently the extract of Cimicifuga racemosa (CR) is utilized as a phytotherapic drug used in the treatment of climacteric symptoms in women to whom the conventional hormonal replacement therapy is counter-indicated. However, the central nervous system (CNS) effects of this phytotherapic in not well known. The aim of this study was to evaluate the neurobehavioral effects of the CR by using the Open field, Hole board and Plus maze tests in mice. Methods: The extract of $C$. racemosa (CR) utilized in this study was obtained from Marjan Lab. (Aplause $\AA)$. Male Swiss mice (20-25 g) were randomically divided in five groups ( $\mathrm{n}=6$ animals per group). Mice were treated daily with CR $(1,5,10$ or $25 \mathrm{mg} / \mathrm{kg} / 21$ days; orally) or saline $(0.9 \%)$ and maintained under ad libitum feeding and standard vivarium conditions. On the 21st day, after 1 hour after CR treatment, animals were submitted to neurobehavioral tests (Open-field test, Hole board and Plus maze, respectively). The positive control groups were treated with diazepam (DZP) (2, 1 and $1 \mathrm{mg} / \mathrm{kg}$; i.p., respectively) thirty minutes before behavioral tests. Results: Mice showed an increase $(p<0.001)$ in the immobility time in CR-10 and DZP $(2 \mathrm{mg} / \mathrm{kg})$ groups (116.0 \pm 19.1 and $169.6 \pm 14.7$ seconds, respectively), as compared to saline group $(6.5 \pm 1.5$ s) evaluated by the Open-field test. The groups treated with CR (1,5, 10 or $25 \mathrm{mg} / \mathrm{kg})$ and DZP $(2 \mathrm{mg} / \mathrm{kg})$ showed a decrease of the motor activity in all parameters analyzed, in comparison to saline group evaluated by the Hole board test. Animals treated with CR ( 5 , 10 and $25 \mathrm{mg} / \mathrm{kg})(12.8 \pm 2.1,22.1 \pm 3.8$ and $18.0 \pm 4.8$ number of head dips, respectively) showed a reduction tendency of head dips in relation to DZP $(1 \mathrm{mg} / \mathrm{kg})$ and saline groups (30.0 \pm 1.7 and $26.1 \pm 3.7$ number of head dips, respectively). The data analysis of the Plus maze test revealed a decrease of the entries in the open arms in the groups treated with CR $(1,10$ and $25 \mathrm{mg} / \mathrm{kg})$, in comparison to the DZP (1 mg/kg) group. Conclusions: The $C$. racemosa extract presented a potential reduction in the locomotor activity and exploratory capacity in mice. Based on the current data and on previous results $C$. racemosa extract exerts a possible dose-dependent effect with anxiolytic and hypnotic activity in mice. However, further studies in vivo should be conducted to further determine the role of this phytotherapic on the CNS.

Keywords: Phytotherapic, Behavior, Anxiety

FROTA, A.F.; SOUZA, R.B.; BEZERRA, M.M.; CUNHA, R.M.S.; AGUIAR, L.M.V. 2013. Neurobehavioral effects of chronic administration of Cimicifuga racemosa (I.) nutt. extract in mice, p.20. In: Oriá, Reinaldo Barreto; Andrade, Geanne Matos de; Bruin, Veralice Meireles S. de. I International Symposium in Neuroscience Meeting [Blucher Neuroscience Proceedings n.1 v.1]. São Paulo: Blucher, 2014, http://dx.doi.org/10.5151/isnm-sine15 